\title{
John Makeham, Lost Soul, Confucianism in Contemporary Chinese Academic Discourse
}

\section{Sébastien Billioud}

\section{(2) OpenEdition \\ 12 Journals}

\section{Electronic version}

URL: http://journals.openedition.org/chinaperspectives/4263

DOI: $10.4000 /$ chinaperspectives.4263

ISSN: 1996-4617

\section{Publisher}

Centre d'étude français sur la Chine contemporaine

\section{Printed version}

Date of publication: 1 July 2008

Number of pages: 152-153

ISSN: 2070-3449

\section{Electronic reference}

Sébastien Billioud, « John Makeham, Lost Soul, Confucianism in Contemporary Chinese Academic Discourse », China Perspectives [Online], 2008/3 | 2008, Online since 01 July 2008, connection on 21 September 2020. URL : http://journals.openedition.org/chinaperspectives/4263 ; DOI : https://doi.org/ 10.4000/chinaperspectives.4263

\section{This text was automatically generated on 21 September 2020}

(C) All rights reserved 


\title{
John Makeham, Lost Soul, Confucianism in Contemporary Chinese Academic Discourse
}

\author{
Sébastien Billioud
}

1 In describing the transformation of modern Confucianism into discourses disassociated from the whole body of practices to which it was traditionally attached, the historian Yu Yingshi has compared it to a wandering soul (you hun) and wonders if Confucianism will ever be able to "borrow a corpse to enable the soul to return" (p.2). The peregrinations of this soul since China's opening up, and the consequent multiplicity of contemporary academic discourses on Confucianism, provide the focus of interest for John Makeham's rich monograph. Makeham's 397-page work consists of an introduction followed by 14 chapters divided into four sections, a conclusion, a bibliography, and an index.

2 The first section (chapters one to four) provides the historical background to the current debates. Makeham's first proposition is that the thesis of a "Confucian capitalism" put forward in Singapore in the 1980s contributed greatly to the potential for the subsequent resurgent interest in Confucianism in mainland China. In this respect, he emphasises the role played by one figure, the Harvard professor and philosopher Du Weiming, whose strategy for reintroducing Confucianism to the centre of debates on the mainland consisted initially of exporting it abroad (Singapore, the US etc.) so as to re-import it later (chapter one). Although the communist authorities enabled academic discussion of Confucianism to take place in the late 1980s, Makeham goes on to show that the argument through which those authorities actually sought to integrate Confucianism into their own ideological agenda at that time is simply not defensible (chapter two). The next two chapters deal with the context for the enormous expansion of Confucian studies in China in the 1990s, and their interaction with research projects on the same topic in Taiwan.

3 In the second section (chapters five to seven), the author focuses on the way in which intellectuals today think about the relationship between Confucianism and Chinese 
culture in general. He begins (in chapter five) by detecting a clear and quite widespread propensity to assimilate the idea of a Chinese cultural identity with Confucianism, and he lists in particular the large number of attempts to make a distinction between the positive (still useable) traditional elements and the negative "feudal" ones (to be rejected). In chapter six, he goes on to examine more closely the case of two intellectuals, Guo Qiyong and Zheng Jiadong, whom he considers to "have been instrumental in shaping an attitude of sympathetic understanding" towards Confucianism within the academic community (p. 147). Finally, he examines the contemporary debates over the proper meanings to be attributed to the ancient notion of daotong, which refers to the interconnecting thread of the Way (the Dao), but which is also capable of sustaining a cultural nationalism based on an essentialist conception of the Chinese cultural tradition.

The third section, which is perhaps the richest, breaks with a certain discursive consensus unveiled in the previous one. It deals with some of the debates that raise, in varying degrees, the issue of Confucian orthodoxy today. It starts with an analysis of the thought of a Taiwanese intellectual, Lin Anwu, who extols the value of a "critical Confucianism" aimed at going beyond the moral metaphysics (and the proclaimed orthodoxy) of the great contemporary Confucian thinker Mou Zongsan (1909-1995), and thereby engaging in a dialogue with Marxism. Makeham demonstrates that Lin nonetheless remains largely confined within the intellectual agenda formulated by Mou. In the next chapter he turns to the way in which certain Confucian intellectuals on the mainland conceive of the role of the authorities in promoting Confucian teaching, and makes interesting comparisons with the "Chinese cultural renaissance movement" in Taiwan in the 1960s. This is followed by a more technical section in which Makeham brilliantly shows what is at stake, in terms of orthodoxy and cultural nationalism, in the current debates surrounding the recent archaeological discoveries of ancient manuscripts (in Mawangdui, Dingxian, and Guodian). Lastly, the author returns to the relationship between Confucianism and another orthodoxy, Marxism in this instance, by addressing the question of a Confucian-Marxist synthesis.

In the final section, Makeham concerns himself with discussions of what a Confucian teaching could be today, and the possibilities of its diffusion. He broadens the perspective and addresses militant discourses that do not necessarily arise from within the academic world. The first chapter presents some of the ideas of Jiang Qing, an apostle of cultural nationalism and of a combined political and religious Confucianism, who enjoys the support of a small group of intellectuals and certain high-ranking officials. Makeham follows this with an analysis of the ancient debate, raised again in the late 1970s, concerning the relationship between Confucianism and religion. His illuminating survey of the various positions ends with the role of the Confucian Academy of Hong Kong in promoting a religious and political version of Confucianism on the mainland. ${ }^{1}$ The concluding chapter examines the propagation of Confucian values in society by taking three different examples: the promotion of traditional virtues, of the recitation of the classics, and of the ideal of the exemplary Confucian entrepreneur (rushang).

6 One can only express admiration for John Makeham's huge achievement in terms of both documentation and detailed analysis, which gives the reader access to a full account of the debates over Confucianism since China's opening up. Throughout the work we are able to make our way with ease through sometimes complex issues, as the 
author clearly expounds the various positions taken as well as the underlying issues. Although the material is sometimes of a technical nature, Makeham still manages to be usefully instructive by summarising the principal points in his provisional conclusions at the end of each chapter, and, whenever necessary, by providing additional information that makes the context easier for a less informed reader to grasp. (For example, there is a useful appendix on the philosophy of Mou Zongsan). Moreover, the numerous passages from Chinese works, carefully translated and accompanied by commentary, allow readers to make their own direct assessments of the different debates.

7 Makeham is convincing on the main issues developed through his book. He is enlightening on how the production of discourses on Confucianism on the mainland has been influenced by emulation of, and academic rivalry with, overseas Chinese intellectuals. By tracing the origins and the history of all the debates, he also effectively demonstrates that the widespread idea that Confucianism is promoted in academic circles by the government is really far too simple (one could nevertheless ask whether such an idea has ever been anything more than a cliché). And one can only agree with him when he links contemporary Confucian discourse with a nationalism based on culture rather than on the State. But we might still wonder whether explaining it in terms that tend to relate everything to nationalism (p. 333) might not be too reductive.

Since this work focuses on contemporary intellectual discourse, one of its limitations may be to have taken only marginal account of pronouncements on Confucianism by scholars who are not primarily specialists in that field (such as Liu Xiaofeng or Qin Hui). It is striking how such views have proliferated over the last few years. This development echoes a wider resurgent interest throughout society in "national studies," some elements of which (as with the classics reading movement) have indeed been emphasised by the author.

9 These observations in no way detract from the value of the work. Lost Soul constitutes a most valuable source for understanding the ways in which Confucianism is staging a comeback in post-Maoist China. In this volume John Makeham has given us a major work that will certainly become a durable reference for all those interested in the contemporary fate of the Confucian tradition.

\section{NOTES}

1. On this point, see the article by Sébastien Billioud and Joël Thoraval in this issue of China Perspectives. 